\title{
Income Heterogeneity and Environmental Kuznets Curve in Africa
}

\author{
Adeyemi A. OGUNDIPE ${ }^{1}$, Philip O. ALEGE $^{1}$ \& Oluwatomisin M. OGUNDIPE ${ }^{1}$ \\ ${ }^{1}$ Department of Economics and Development Studies, Covenant University, Ota, Ogun State, Nigeria \\ Correspondence: Department of Economics and Development Studies, Covenant University, Ota, Ogun State, \\ Nigeria. Tel: 234-81-6192-7372. $\quad$ E-mail: ade.ogundipe@covenantuniversity.edu.ng; \\ yemi_keke2001@yahoo.com
}

Received: June 4, 2014 Accepted: June 28, 2014 Online Published: July 31, 2014

doi:10.5539/jsd.v7n4p165

URL: http://dx.doi.org/10.5539/jsd.v7n4p165

\begin{abstract}
The Environmental Kuznets Curve (EKC) hypothesis asserts that pollution levels rises as a country develops, but reaches a certain threshold where pollution begins to fall with increasing income. In EKC analysis, the relationship between environmental degradation and income is usually expressed as a quadratic function with turning point occurring at a maximum pollution level. This study seeks to examine the pattern and nature of EKC in Africa and major income groups according to World Bank classification comprising low income, lower middle income and upper middle income in Africa. In ensuring the robustness of our study; the paper proceeded by ascertaining the nature of EKC in all fifty-three countries of Africa in order to confirm the results obtained from basic and augmented EKC model. The study could not validate EKC hypothesis in Africa (combined), low income and upper middle income but empirical and analytical evidences supports the existence of EKC in lower middle income countries. Likewise, evidences from the robustness checks confirmed the findings from the basic and augmented EKC model. The study could not attain a reasonable turning point as there are evidences that Africa could be turning on the EKC at lower levels of income. Also, there is need to strengthen institutions in order to enforce policies that prohibits environmental pollution and ensure pro-poor development agenda.
\end{abstract}

Keywords: pollution, income, Environmental Kuznets Curve, Africa

\section{Introduction}

The concept of EKC originated from Kuznets (1955) who hypothesized that income inequality first rises and then falls as economic development proceeds but the concept actually emerged via the path breaking study of Grossman and Krueger on the potential environmental impacts of NAFTA in 1991. The Environmental Kuznets Curve (EKC) postulates the relationship between per capita income and indicators of environmental degradation. It suggests that in the early stages of economic growth, degradation and pollution increases but beyond some levels of income per capita which will vary for different indicators, the trend reverses, so that high income levels leads to environmental improvement. It thus implies that the environmental impact indicator is an inverted U-shaped function of income per capita (Stern, 2009). According to Lomborg (2001) who draws on the World Bank's World Development Report (1992) which contained one of the first environmental Kuznets curve (EKC) studies, later published by Shafik (1994); the EKC refers to an empirical finding which indicates an inverted U-Shaped relationship between local air pollution and per capita income.

An attempt to validate EKC model in Africa has results into diverse results, with empirical studies of Baliamoune-Lutz (2012); Osabuohien, Efobi and Gitau (2014) validating the hypothesis while Omotor and Orubu (2001); Orubu and Awopegba (2009) failed to confirm the existence of EKC. The mixed findings arising from the empirical investigation of EKC could have arisen from income heterogeneity in Africa economies. Since income and development levels differ among these economies, the realization (non-realization) of EKC in Africa cannot be used to affirm the existence (non-existence) of EKC in individual Africa economies. Perman and Stern (2003) argued that there is a doubt on the general applicability of EKC because even when cointegration relationship was established between variables in the region, many of the relationships for individual countries were not concave. Therefore, this re-examination of EKC model in Africa controls for cross country income heterogeneity by grouping Africa economies based on World Bank classifications of low income, lower middle income and upper middle income and investigated the nature of EKC in each income group accordingly. In validating the result from our model and extant studies, this current attempt ascertained the nature of EKC and turning points in the individual fifty-three Africa economies. 
The hope for the future is conditional on decisive political action now to begin managing environmental resources to secure both sustainable human progress and human survival. Inquest for every nation to actualize some economic successes, there has been obvious threat to the environment. Each year witnesses several hectares of productive dry-land turns into worthless desert, likewise more than 11 million hectares of forests are destroyed yearly. In Europe, acid precipitation kills forests and lakes and damages the artistic and architectural heritage of nations. The world is experiencing global warning arising from consistent burning of fossil fuels into the atmosphere. The green house effect has the potential to mitigate agricultural production, raise sea levels to flood coastal cities and disrupt national economies (UN Environmental Report 1993).

Other industrial gases threaten to deplete the planet's protective ozone shield to such an extent that the number of human and animal cancers would rise sharply and the oceans' food chain would be disrupted. From the foregoing and the popularization of EKC, it becomes clear that the acquisition of economic growth and the need to ensure cleaner quality environment are inseparable issues. Many forms of development erode the environmental resources and on the long-run environmental degradation can jeopardize economic development. In an attempt to ensure realization of present needs that will not distort the ability of the future generations to meet their needs; there is need for policy makers, national government and international institutions to implement policy and guidelines for production and extractive processes and enforce adequate abatement measures (Alege \& Ogundipe, 2013).

Our work is related to numerous attempts to explain the pollution growth nexus. Most studies test the validity of the so called EKC hypothesis which postulates an inverted U-shaped relationship between environmental degradation and income growth (see Grossman \& Krueger, 1994; 1995).

The study conducts inferences on the relationship between the development stage and pollution dynamics of Africa countries in order to draw policy implications. Our study emphasize a dynamic processes where the relationship between environmental degradation and income levels is considered, disaggregating Africa economics into low income, lower middle income, upper middle income and high income countries. Though, erstwhile study on the subject matter (Osabuohien et al., 2014) have aggregated the economies of Africa but considering the intent of $\mathrm{EKC}$, to appropriately capture its nature in Africa where economies exhibit heterogeneity of income; it becomes imperative to disaggregate countries according to income level. Our study hereby attempt to ascertain if a country's income level does matter for its pollution dynamics; since its current development stage influences its future pollution prospect. Also, examine the pattern and direction of relationship between pollution and income; and determine the speed of realization of EKC (if it does exist) in the face of various interventions/abatement measures. This enables policy makers and environmental activist to ensure appropriate actions needed to assume sustainable development.

The remaining part of the paper is structured as follows: section two situates the experience of Africa with the rest of the world and analyses the $\mathrm{CO}_{2}$ emissions and income relationships in income groups in Africa; section three outlines the related literature that situate our study in the context of existing literature; section four put forward the model appropriate for an empirical investigation of EKC in Africa; section five discusses the empirical results and findings from the estimation procedure while section six concludes the paper and offers some policy recommendations.

\section{Stylized Facts/Background Information}

This section presents the state of environmental pollution in Africa in comparison to the rest of the world. Figure one shows that $\mathrm{CO}_{2}$ emissions have consistently maintained an upward trend in Africa and the rest of the world. This was the basis for the establishment of Kyoto protocol and initialization of commitment to reduce the level of $\mathrm{CO}_{2}$ emissions since it constitutes the largest contributor to the share of total green house gases (GHGs) in the world (Bank Bank, 2007). In the same manner, table one shows the regional contribution to the total world $\mathrm{CO}_{2}$ emissions, with Africa share steadily increasing raging from 1.78 percent to 2.5 percent and eventually 2.17 percent in period 1971-1980, 1981-1990 and 2001-2010 respectively. In relative terms, Africa has contributed minimally to the world $\mathrm{CO}_{2}$ emissions when compared to other regions. East Asia and pacific contributes 15.56 percent, 25.55 percent and 30.84 percent in the same periods. Likewise Europe, Latin America and Middle East have contributed more than 5 percent (between 5 and 30 percent) to $\mathrm{CO}_{2}$ emissions for the observed periods. In spite of Africa lower relative contributions, Osabuohien et al (2014) claimed that in absolute terms, $\mathrm{CO}_{2}$ is has risen consistently over the periods amounting to about 451 percent between 1960 and 2008. 


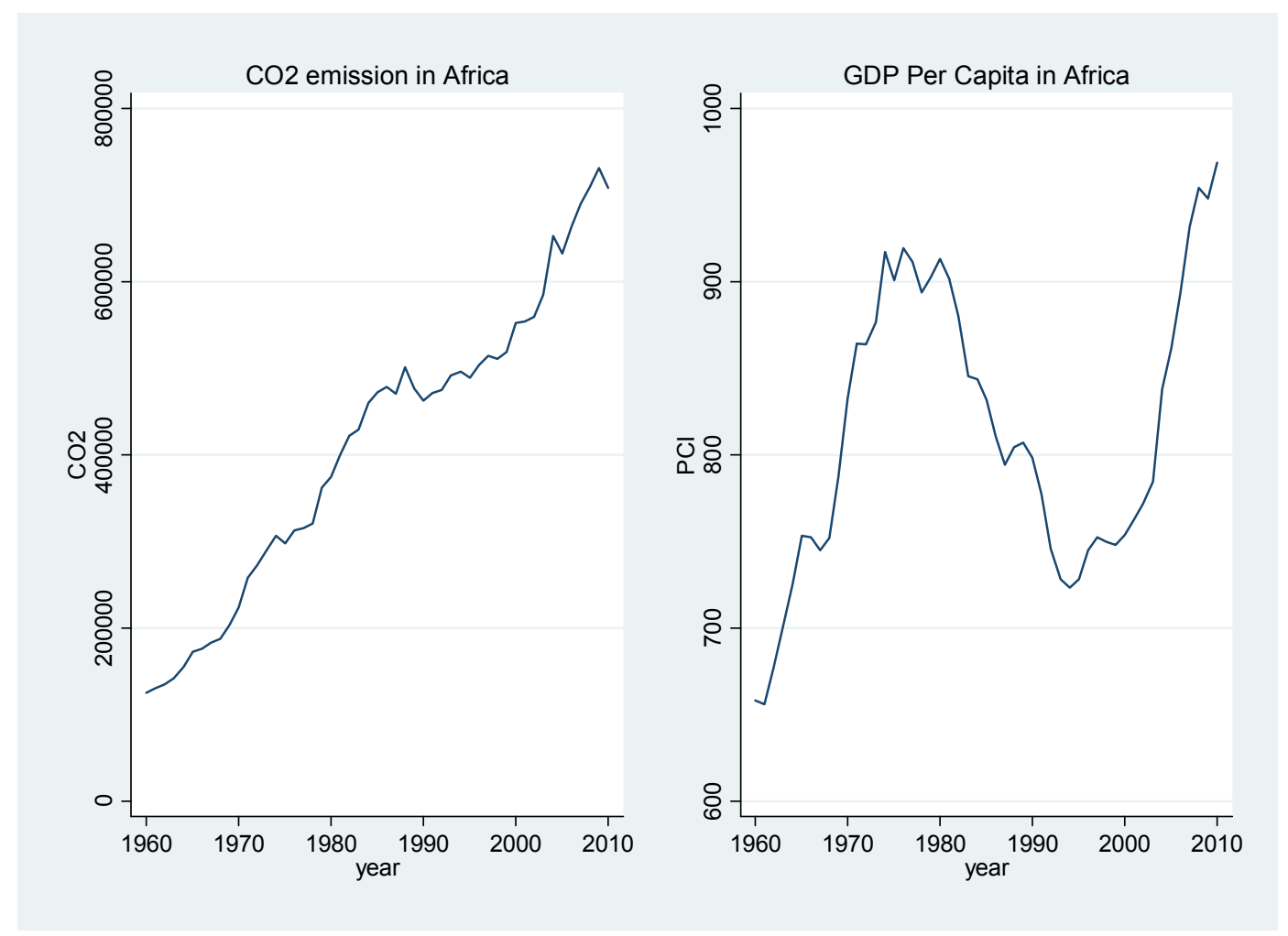

Figure1. Trend of $\mathrm{CO}_{2}$ emissions (kt) and GDP Per Capita in Africa

Source: Authors' computation from WDI (2013)

Also, table 2 shows the sectoral contributions to world $\mathrm{CO}_{2}$ emissions according to six regional divisions for which statistics were available. As seen in the table, East Asia and the pacific account for the largest $\mathrm{CO}_{2}$ emissions in manufacturing, industries and construction sectors with about 60 percent rise in the period 1970-2011. Likewise, Europe, Latin America and the Middle East share witnessed steady increase while Africa's contribution dwindled overtime. This evidence would not be unconnected to the weak manufacturing capacity and industrial exports in Africa, which contribute less than 10 percent to merchandise exports. More so, due to high fossil fuel consumption in Africa; the transport sector share of world emissions has maintain an upward trend from 2 percent in 1971-1980 to about 3 percent in 2011. Likewise, the same upward trend was witnessed in Latin America, Middle East and South Asia while Europe and central Asia reduce the level of transport $\mathrm{CO}_{2}$ emissions. This is likely due to adoption of clean technologies as a result of increased income levels and development.

Table 1. $\mathrm{CO}_{2}$ emissions (kt) as a percentage contribution to the world $\mathrm{CO}_{2}$ emissions

\begin{tabular}{lllll}
\hline Regions & $\mathbf{1 9 7 1 - 1 9 8 0}$ & $\mathbf{1 9 8 1 - 1 9 9 0}$ & $\mathbf{1 9 9 1 - 2 0 0 0}$ & $\mathbf{2 0 0 1 - 2 0 0 8}$ \\
\hline East Asia \& Pacific & 15.65 & 19.52 & 25.55 & 30.84 \\
Europe \& Central Asia & n.a & n.a & 29.71 & 23.77 \\
Latin America \& Caribbean & 4.00 & 4.66 & 5.16 & 5.18 \\
Middle East North Africa & 2.94 & 3.88 & 5.20 & 6.09 \\
South Asia & 1.75 & 2.90 & 4.59 & 5.58 \\
Africa $^{\text {a }}$ & 1.78 & 2.27 & 2.15 & 2.17 \\
\hline
\end{tabular}

Source: Authors' computation from WDI (2013)

Note: n.a means not available

${ }^{a}$ Sub-Saharan is used to capture Africa, as Africa was not classified in the WDI data base 
Grossman and Krueger (1991) established that the pollution-income relationship tends to rise with increasing income at early growth stages. However, when the curve reaches a threshold (turning point) environment begins to improve at higher stages of growth. This assertion is reflected in the so called inverted U-shaped curve, expressing the relationship between pollution and income. As seen in figure 2, we could not ascertain the direction of pollution-income relationship until the point USD800. From this point, the pattern became stable and consistent with expected behaviour at early growth stages but is yet to witness an identifiable turning point. If the empirical claim of Omotor and Orubu (2012) is to be relied upon, the curve might experience a threshold at about USD1344.63, from which higher level of growth will lead to improving the environment.

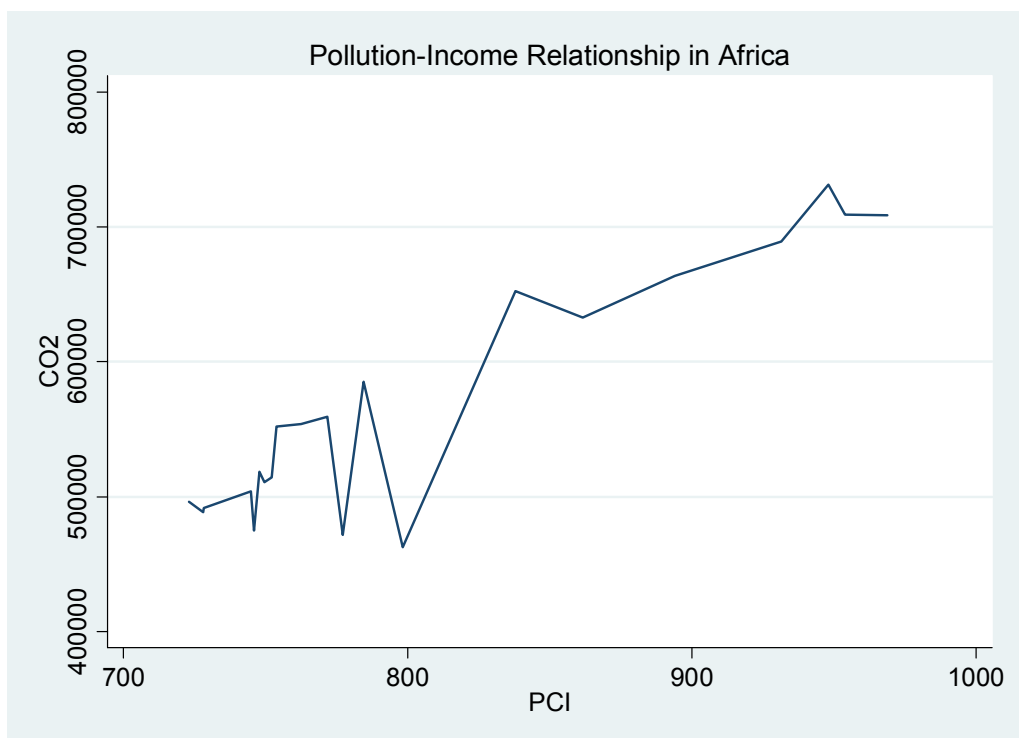

Figure 2. Pattern of pollution-income relationship in Africa

Authors' computation from WDI (2013)

The major threat to environment centres is how to ensure sustainable environment, adopt cleaner environment and adopt abatement measures in the face of poverty in the developing economies. Poverty is adjudged a major cause of environmental problems in developing economies. Therefore, balancing the immediate needs of survival with long run sustainability is the issue at hand and requires policy interventions capable of reducing extreme poverty and extent of income inequality. The foregoing are the concerns that lead to the establishment of the world commission on environment and development by UN General Assembly in 1993. 
Table 2. Sectoral $\mathrm{CO}_{2}$ emission as percentage contribution to the world sectoral $\mathrm{CO}_{2}$ emissions

\begin{tabular}{|c|c|c|c|c|c|c|}
\hline & & 1971-1980 & 1981-1990 & 1991-2000 & 2001-2010 & 2011 \\
\hline \multirow[t]{6}{*}{ Manufacturing, Industries \& Construction } & East Asia \& pacific & 24.3 & 29.8 & 39.5 & 46.3 & 51.0 \\
\hline & Europe and central Asia & NA & NA & 26.8 & 20.3 & 16 \\
\hline & Latin America \& Caribbean & 4.1 & 4.9 & 5.9 & 6.0 & 6.0 \\
\hline & Middle East North Africa & 1.2 & 2.0 & 2.7 & 3.0 & 3.1 \\
\hline & South Asia & 2.2 & 3.5 & 5.2 & 6.5 & 8.1 \\
\hline & Africa & 2.0 & 2.2 & 1.9 & 1.6 & 1.6 \\
\hline \multirow[t]{6}{*}{ Residential, Commercial \& Public Services } & East Asia \& pacific & 13.7 & 19.9 & 22.0 & 24.5 & 27 \\
\hline & Europe and central Asia & 50.5 & 47.8 & 39.1 & 35.2 & 33 \\
\hline & Latin America \& Caribbean & 1.9 & 2.7 & 3.5 & 4.1 & 4 \\
\hline & Middle East North Africa & n.a & n.a & n.a & n.a & n.a \\
\hline & South Asia & 1.4 & 2.1 & 3.2 & 3.8 & 4.6 \\
\hline & Africa & NA & NA & NA & NA & NA \\
\hline \multirow[t]{6}{*}{ Transport } & East Asia \& pacific & 10.6 & 13.9 & 16.9 & 20.1 & 23 \\
\hline & Europe and central Asia & 29.9 & 30.0 & 26.8 & 24.3 & 22 \\
\hline & Latin America \& Caribbean & 7.0 & 7.6 & 8.2 & 8.7 & 10.0 \\
\hline & Middle East North Africa & 1.5 & 2.7 & 3.6 & 4.5 & 4.9 \\
\hline & South Asia & 2.0 & 2.4 & 2.8 & 2.9 & 3.8 \\
\hline & Africa & 2.0 & 1.9 & 1.8 & 2.2 & 2.5 \\
\hline
\end{tabular}

Source: Authors' computation from WDI (2013)

Note: n.a indicates not available
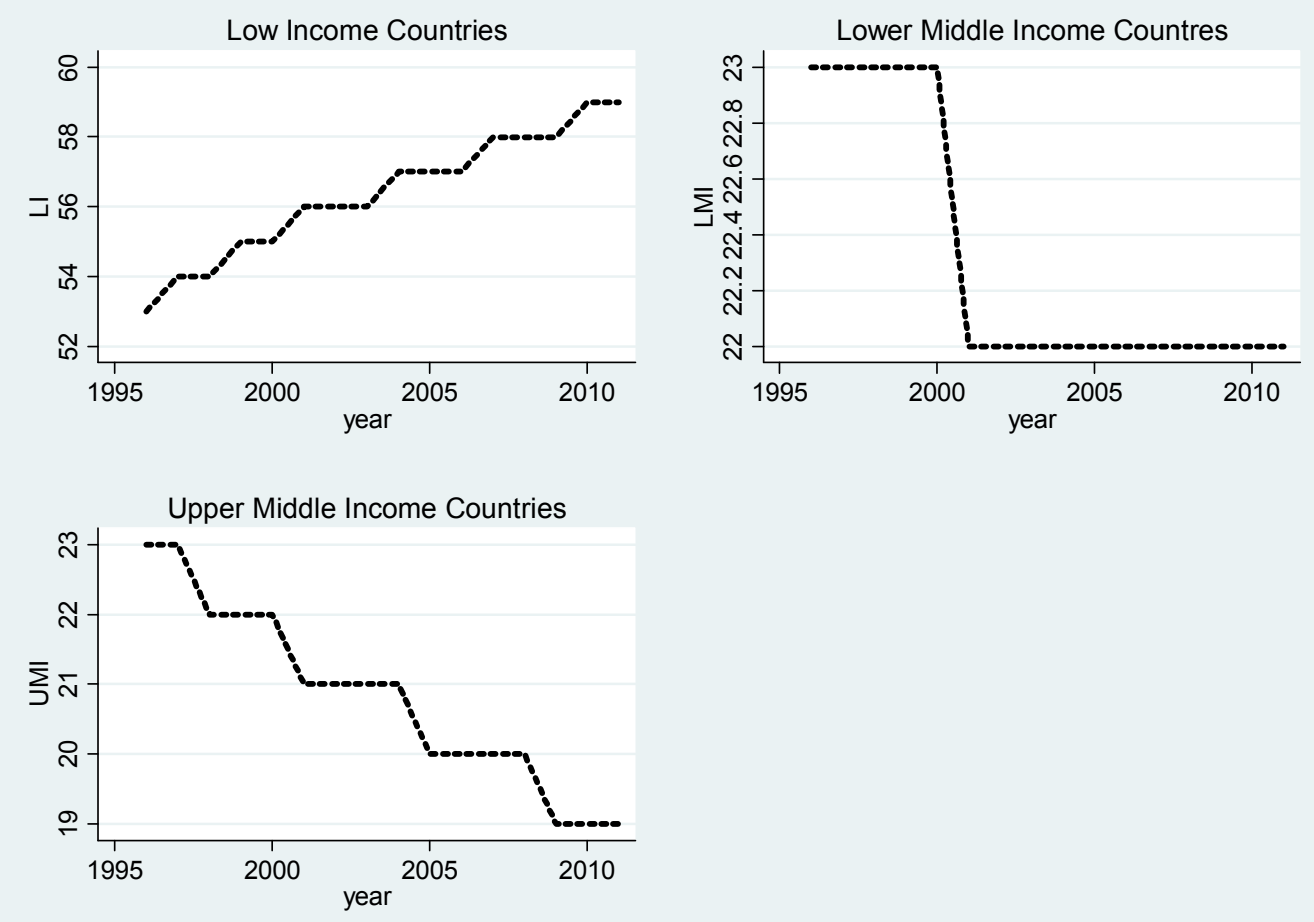

Figure 3. Group $\mathrm{CO}_{2}$ emissions (kt) as percentage contribution to Africa's $\mathrm{CO}_{2}$ emissions

Source: Authors' computation from WDI (2013) 
It becomes clear from evidences in figure 3 and table 3, that poverty fuels environmental degradation in Africa. The carbon dioxide, $\mathrm{CO}_{2}$, share of the low income countries (which constitute 51 percent of Africa economies) in Africa's total $\mathrm{CO}_{2}$ emissions has been rising steadily, from 53 percent in 1996 to 60 percent in 2011. Whereas, the share of GDP per capita of these economies in Africa's' average has fallen considerably over the same period. This singular fact has accounted for mixed finding on the nature of EKC in Africa, since extant failed to control of income differences across Africa economies. This also confirms one of the conclusions of Lipfert (2004) that "though poor people may be more susceptible, but poverty also fosters increased pollution". In the spirit of EKC, Hollander (2003) describes the problem of poor as the inability to deal with pollution until they acquire affluence to meet their basic needs for survival.

Table 3. GDP per capita and $\mathrm{CO}_{2}$ emission as a percentage contribution to Africa's total

\begin{tabular}{lllllllll}
\hline Year & $\mathbf{1 9 9 6}$ & & $\mathbf{2 0 0 0}$ & & $\mathbf{2 0 0 6}$ & \multicolumn{3}{c}{$\mathbf{2 0 1 1}$} \\
\hline Group & $\mathrm{PCI}$ & $\mathrm{CO}_{2}$ & $\mathrm{PCI}$ & $\mathrm{CO}_{2}$ & PCI & $\mathrm{CO}_{2}$ & PCI & $\mathrm{CO}_{2}$ \\
\hline Low income & 29.3 & 53.5 & 24.0 & 55.2 & 21.2 & 57.3 & 22.2 & 59.3 \\
Lower middle income & 92.2 & 22.3 & 84.0 & 22.6 & 84.4 & 22.0 & 89.4 & 21.6 \\
Upper middle income & 363 & 22.9 & 374 & 21.7 & 345 & 20.2 & 313 & 18.6 \\
\hline
\end{tabular}

Source: Authors' computation from World Development Indicators (WDI) (2013)

Note: PCI is per capita income.

A critical observation of table 3 shows that statistics available in different income groups does not validate the EKC hypothesis except in the lower middle income group. In low income Africa, $\mathrm{CO}_{2}$ emissions rises as per capita income falls; $\mathrm{CO}_{2}$ rises from 53.5 percent in 1996 to 57.3 percent and 59.3 percent in 2006 and 2011, respectively. Also, in the upper middle income group, the share of GDP per capita in Africa's average falls consistently with increasing $\mathrm{CO}_{2}$ emissions indicating a U-shaped relationship. Contrarily, in the lower middle income, emissions falls from 22.6 percent in 2000 to 22 percent in 2006 and further to 21.6 percent in 2011 while GDP per capita share rises from 84 percent to 84.8 percent and peak at 89.4 percent in 2000,2006 and 2011 respectively. The trend witnessed in the lower middle income group validates the inverted U-shaped hypothesis of EKC.

The evidence in table 3 re-affirm the core thrust of this study and the need to control for income heterogeneity in ascertaining the pattern and nature of EKC in Africa and as well as examines the specific nature and turning points in individual country.

\section{Review of Related Literature}

The EKC theme was popularized by the World Development Report 1992 (IBRD 1992) which argued that: "the view that greater economic activity inevitably hurts the environment is based on static assumptions about technology, tastes and environmental investments" and that "as income rise, the demand for improvements in environmental quality will increase, as will the resources available for investment. Others have also explicated this position even more forcefully, for instance Beckerman (1992) claimed that "there is clear evidence that, although economic growth usually leads to environmental degradation in the early stages of the process, in the end the best and probably the only way to attain a decent environment in most countries is to become rich".

As cited by Cole (2003), Lomborg (2001) in his book "skeptical environmentalist" shared the opinion of Beckerman (1992) strongly. Lomborg argues that although air pollution emissions are rising in many developing countries, the EKC indicates that it is possible to "grow out" of environmental problems through technological advance and appropriate environmental policy. Thus, he claims that today's developing countries should one day experience reductions in pollution as currently enjoyed in developed world. He opined that emissions of virtually all local air pollutants have fallen steadily in the developed world over the last 30-40 years. Lomborg (2001) confirmed this assertion by providing emissions and concentration trends for the United Kingdom and the United States of America. Similar conclusion was made for the United States of America in the cases of lead, particulates, sulphur dioxide, nitrogen dioxide and carbon monoxide and concludes that air quality in these countries has significantly improved.

Asserting from the study conducted by Grossman and Krueger (1995), Cole et al (1993), Alege and Ogundipe (2013), the EKC relationship is explained in terms of the interaction of scale, composition and technique effects. 
The scale effect indicates that, ceteris paribus, economic growth will increase pollution. However, with increasing per capita income, the economy experiences a compositional change from manufacturing to services. The effect of these changes would likely result in reducing pollution intensity of output. More so, as the nation continue to experience a leap in per capita income and as welfare improves, it is argued that the demand for cleaner environment rises, culminating into positive income elasticity of demand for environmental quality and consequently increases in demand for environmental regulations. In the words of Cole (2003), this resultant changes to the technique of production are known as the technique effect. The combination of technique and composition effects, therefore, eventually outweighs the scale effect, resulting in the downturn of EKC.

Considering the composition effect, there seems to be a challenge for Less Developed Countries (LDCs), especially resource-abundant LDCs. The case of LDCs may not follow the same pollution-income path experienced in developed economies. If the pollution intensity of output has fallen in the North as a result of the migration of heavy industry to the South due to: (i.) proximity to resource area (ii.) proximity to market (iii.) Market displacement of Northern industries by Southern industries (iv.) Strict environmental regulation in the North e.t.c, then, it is unlikely that the south can expect to enjoy similar reductions in pollution intensity. The study by Suri and Chapman (1998) found lower emissions with increased manufactured imports and found higher emissions with increased exports; it hereby suggests that compositional changes, as reflected in changing trade patterns, are influencing energy consumption and hence pollution.

Likewise, there are inherent problem in developing countries that could mitigate the transition from scale to composition effect; this factors include the following: (i.) attraction of dirty industries into the extractive industry (ii.) weak governance and heavy incidence of corruption (iii.) weak environmental regulation and lack of enforcement, and (iv.) extremely skewed income, which continually widen inequality gap and subjected the poor to degrading the environment to maintain survival. Cole (2000) also find that the increasing cleanliness of the composition of manufacturing sector is at least partly responsible for falling pollution in the developed world. Contrarily, Janicke et al., (1997) shows that the North is still a net exporter of many pollution intensive products, suggesting that each compositional change may not be as significant as proposed. Though, pollution haven hypothesis (Note 1) has found limited support (Mani and Wheeler (1998), Lucas et al., (1992), Birdsaff and Wheeler (1993) likewise some empirical studies document a little evidence of the formation of pollution havens Xu and Song (2000), Tobey (1990), Van Beers and Van De Bergh (1997)). Contrarily, the work of Antweiler et al (2001), Cole and Elliot (2003) found evidence of pollution haven pressures. This is likely to have resulted from the fact that many pollution intensive sectors in the LDCs are highly capital intensive and most suited for the capital abundant North.

It is also generally recognized that environmental concern is income elastic: countries and social groups increase their interest in environmental quality as their income rise Ruttan (1971), Ciriacy-wantrup (1963), Chapman and Barker (1991). If environmental improvement is to succeed increased income, there seems to be a problem for Africa, especially the natural resources dependent economies. The rent-seeking behaviour of multinationals and economic agents involved extraction which arises from weak institutions tends to dissipate the benefits of economic resources and lengthen the vicious cycle of poverty. Since most rural poor depend on local economic activities for survival as the level of poverty expands, environmental degradation worsens. As stated crudely put by Chapman (1993), at population-intensive subsistence levels, rural households are more interested in consuming wildlife than its protection for the enhancement of future generation. As the economy grows, there is need for policies that will enhance both natural living standard and environmental protection in the world's poorest countries.

Perrings (1989, 1991), Clark (1991), and Ciricay-Wantrup (1963) have argued that low income causes high discount rates. If this is correct, it confirms the widely shared observation that very poor regions seem to degrade renewable resources stocks far below economically optimal levels (Chapman, 1990; Moyo, 1991).

Grossman and Krueger (1991) in their pioneer study of EKC, investigate the potential environmental impacts of NAFTA. They developed a cross-country panel that estimated $\mathrm{EKCs}$ for $\mathrm{SO}_{2}$, dark matter (fine smoke), and suspended particles M(SPM) using Global Environmental Monitoring System (GEMS) data set for 42 developing and developed countries (Note 2). The empirical work by Grossman and Krueger found evidence supporting EKC patterns for $\mathrm{SO}_{2}$ and SPM. The turning points for both pollutants were precisely estimated at US\$4772- US\$5965 while the concentration of suspended particles appeared to decline even at low income levels. Following the idea of Grossman and Krueger (1991), Shafik and Bandhopadhyay (1992) were the first to conduct a major empirical study in ascertaining the EKC hypothesis. The study adopted different functional relationship to estimate EKCs for ten indicators. EKC was not attained for deforestation. However, lack of clean water and lack of urban sanitation were found to decline uniformly with increasing income over time. Contrarily, 
municipal waste and carbon emissions per capita increased unambiguously with rising income, while river quality tended to worsen with increasing income.

Naimzada and Sodini (2010) examine the dynamics of an Overlapping Generation (OLG) model with environment, a Constant Elasticity of Substition (CES production) function and agents who invest in environment, taking the action of other agents of the same generation as given. The authors show the possibility of a high income, low environment steady-state when total factor productivity increase over a threshold value and the elasticity of substitution between capital and labour is sufficiently lower. Varvarigos (2010) studies a model where: (a) longevity is positively affected by public health spending and negatively influenced (b) environmental degradation is positively influenced by pollution due to production and it is mitigated by public environment expenditure. He proves that low income - low pollution equilibra are possible depending on the elasticity of (i) environmental damage with regard to pollution (ii) environmental improvements with respect to abatement policy. The likelihood of traps is also a function of the cleanliness of production technology, total energy productivity and initial conditions.

This paper is related to numerous attempts to explain the pollution-growth nexus. Most studies test the validity of the so called Environmental Kuznets Curve hypothesis, which postulates an inverted U-shape relationship between environmental degradation and income (Grossman \& Krueger, 1994, 1995; Osabuohien et al., 2014; Beckerman, 1992; Stern, 2003), while others such as (Agra \& Chapman, 2008; Galeotti et al., 2006; Coondoo \& Dinda, 2008) failed to validate the hypothesis. Although numerous studies test the EKC hypothesis, for individual countries (Friedl \& Getzner, 2003; Roca et al., 2001; De Bruyn et al., 1998; Roberts \& Grimes, 1997) and panel of countries (Canes et al., 2003; Stern, 2004; Perman \& Stern, 2003; Huang \& Cin, 2007) empirics have failed to yield conclusive result (Aslanidis, 2009; Soyas \& Sari, 2009; Bassetti et al., 2008). Moreover, most empirical studies are considered to be econometrically weak (Stern, 2004; Narayan \& Narayan, 2010; Brock \& Taylor, 2010). In a recent study, Narayan and Narayan (2010) examine the EKC hypothesis in a panel of 43 developing countries using panel cointegration in order to overcome econometric pitfalls. They conclude that $\mathrm{CO}_{2}$ emissions fall as income rises only in Middle Eastern and South Asian countries. Finally, Brock and Taylor (2010) employ the Green Solow model as an alternative framework and present robust evidence of convergence between the 173 countries examined using standard panel technique.

In a parallel strand of research, environmental convergence (using $\mathrm{CO}_{2}$ emissions) is examined. In recent work, Bulte et al., (2007) argue that income convergence leads to pollutant emissions convergence. Overall findings on environmental convergence alone are contradictory, as a number of scholars support the hypothesis of convergence in $\mathrm{CO}_{2}$ emissions per capita (Strazicish \& Lit, 2003; Romero-Avila, 2008; Westerland \& Basher, 2008) whereas others provide evidence of divergence (Nguyen-Van, 2005; Barassi et al., 2008). Finally, in a study related to our work, Aldy (2006) shows that Markov chain analysis does not provide convincing evidence on future emissions convergence. The author finds evidence of convergence among 23 OECD countries, whereas emissions appear to be diverging for a global sample composed 88 countries for 1960-2000. Xepapadeas (1997) analyses an endogenous growth model with productive and abatement capital as well as increasing returns due to knowledge spillovers in production and pollution abatement. He shows that countries with environmental concerns can be trapped in a low growth process, high pollution equilibrium because of insufficient knowledge of pollution abatement.

\section{Methodology}

\subsection{Model Specification}

This study adopts a standard presentation and framework of basic EKC model as presented in Chapman and Agra (1999), Omotor and Orubu (2003), and Al sayed and Sek (2013). Their specification assumes environmental degradation as a function income level and the squared of income level; while the former is used to capture the pollution-income relationship at the initial stage of development, the latter accounts for the possibility of turning point, that is, validating the existence of EKC. This specification can be presented as follow:

$$
\ln (\mathrm{ED})_{\mathrm{t}}=\beta_{0}+\beta_{1} \ln \left(\frac{\mathrm{GDP}}{\mathrm{P}}\right)_{\mathrm{t}}+\beta_{2}\left(\ln \left(\frac{\mathrm{GDP}}{\mathrm{P}}\right)\right)_{\mathrm{t}}^{2}+\varepsilon_{\mathrm{t}}
$$

According to Wen and Cao (2009), the theoretical interpretation of the signs and relationship of the parameters (Note 3 ) are as shown below:

a. $\quad \beta_{1}>0, \beta_{2}=0$ indicate linear shape and monotonically increasing. As income rises, environmental pressure is increasing 
b. $\quad \beta_{1}<0, \beta_{2}=0$ represent linear shape and monotonically decreasing. As income rises, environmental pressure is decreasing

c. $\beta_{1}>0, \beta_{2}<0$ indicate inverted U-shape; as reaches a threshold, environmental pressure decreases as income rises

d. $\quad \beta_{1}<0, \beta_{2}>0$ indicate U-shape

e. $\beta_{1}<0, \beta_{2}<0$ indicate reserve $\mathrm{N}$-shape, environmental pressure decreases first; then increases and later decreases

f. $\quad \beta_{1}=\beta_{2}=0$ indicate horizontal line, income does not affect environmental pressure

Presenting our simple EKC model in a panel framework, we have

$$
\ln (\mathrm{ED})_{\mathrm{it}}=\alpha_{\mathrm{i}}+\gamma_{\mathrm{t}}+\beta_{1} \ln \left(\frac{\mathrm{GDP}}{\mathrm{P}}\right)_{\mathrm{it}}+\beta_{2}\left(\ln \left(\frac{\mathrm{GDP}}{\mathrm{P}}\right)\right)_{\mathrm{it}}^{2}+\varepsilon_{\mathrm{it}}
$$

Where $E D_{i t}$ represents environmental degradation, $\left(\frac{G D P}{P}\right)_{i t}$ is GDP per capita, $\beta_{1}$ and $\beta_{2}$ represents the slope of the model, $\alpha_{i}$ and $\gamma_{t}$ are the intercept parameter; $i$ represents the cross-section of countries or regions and $t$ denotes the years or periods of time series and $\varepsilon_{i t}$. Hence, the implicit assumption is that environmental degradation/quality may be different from one country to the other at any given level of income. The income elasticity is the same for all countries at given level of income. On the other hand, the time specific intercepts take care of time-varying variables that are omitted from the model, including stochastic shocks (Omotor \& Orubu, 2001).

In order to establish the stability of EKC model, we introduce other variables relevant in explaining the extent of environmental degradation. According to Chapman and Agras (1999), all empirical investigations of EKC adopts a functional forms capable of evaluating results with respect to the presence or absence of a turning point and the significance of its parameters. The analysis of the relationship of the effect of real per capita income on environmental degradation controlling for other variables relevant to the argument usually assume the form presented below:

$$
\ln (\mathrm{ED})_{\mathrm{it}}=\beta_{0}+\beta_{1} \ln \left(\frac{\mathrm{GDP}}{\mathrm{P}}\right)_{\mathrm{it}}+\beta_{2}\left(\ln \left(\frac{\mathrm{GDP}}{\mathrm{P}}\right)\right)_{\mathrm{it}}^{2}+\varphi_{\mathrm{j}} \sum_{\mathrm{j}=1}^{\mathrm{n}} \ln (\mathrm{X})_{\mathrm{it}}+\gamma_{\mathrm{i}}+\mathrm{u}_{\mathrm{it}}
$$

Where $X_{i t}$ is a vector of explanatory variables added to the basic EKC model such that $X_{i t}=\left\{\right.$ pden $_{i t}$ extd $_{i t}$ mexp $_{i t}$ inst $\left._{i t}\right\}$

Here, $\operatorname{pden}_{i t}$ represents population density (people per sq. km of land area), extd $d_{i t}$ is external debt stock, $\operatorname{mexp}_{i t}$ is an indicator manufactured exports, and inst $t_{i t}$ is a measure of institutions (regulatory quality). The turning point value is $\frac{G D P}{P}(T P)=\mathrm{e}^{-\beta_{1} / 2 \beta_{2}}$

The specification above is similar to the stand by Khanna (2002), who suggested income as one of the factors necessary to ascertain exposure to declining environmental quality. Other factors such as race, education, population density, housing tenure and structural composition of workforce are also relevant (Panayotou, 1997; Torres \& Boyce, 1998). In the words of Omotor et al. (2012) "finding an EKC in the presence of other modifying factors provides a more persuasive basis for validating the hypothesis". In the model above, the basic EKC model was augmented to include factors such as population density, external debt stock, manufactured exports, and regulatory quality. The higher the population density, the greater will be the intensity of pollution and pressure on environmental services and resources. The inclusion of manufactured export as an indicator of trade followed the idea espoused by Wycoff and Roop (1994) as well as Suri and Chapman (1998). If the sign of $\operatorname{lmfxp} p_{i t}$ turns negative, it implies high emissions with increased export, otherwise export mitigate the level of emission.

\subsection{Technique of Estimation}

This paper adopts the panel data analysis to detect the nature of the EKC curve between the pollutants and the economic growth in Africa. Panel data helps to determine dynamic of changes in short time series and provides 
more powerful regression results by considering the place (spatial) and time (temporal) dimensions of the data (Schmidheiny \& Basel, 2011). It as well helps to control for unobservable individual heterogeneity across entities. There are two types of panel model namely; the fixed effect (FE) model and the random effect (RE) model.

The fixed effect model is used in analyzing the impact of variables that vary overtime. It explores the relationship between predictor and outcome variables within an entity (Note 4). The fixed effect removes the effect of those time invariant characteristics from the predictor variables in order to assess the predictors' net effect. The equation for the fixed effect model is shown as:

$$
\begin{gathered}
Y_{i t}=\beta_{1} X_{i t}+\alpha_{i}+u_{i t} \\
u_{i t}=\varepsilon_{i}+\varepsilon_{i t}
\end{gathered}
$$

Where $\alpha_{i}(i=1 \ldots . n)$ is the unknown intercept for each entity (n entity specific intercepts), $Y_{i t}$ is the dependent variable where $i=$ entity and $t=$ time, $X_{i t}$ represents the vector of independent variable, $\varepsilon_{i}$ are time invariant or fixed over time and $\varepsilon_{i t}$ captures the error term. The structure of the model to be estimated with the fixed effects is stated as follows

$$
\operatorname{evdg}_{i t}=\beta_{0}+\sum_{j=1}^{5} \beta_{j} X_{i t}+\sum_{i=1}^{53} \alpha_{i}+u_{t}
$$

Where $X_{i t}=\left\{\begin{array}{l}l^{l p c i_{i t}} \\ \operatorname{lpci}_{i t}^{2} \\ \operatorname{lpden}_{i t} \\ \operatorname{lextd}_{i t} \\ \operatorname{lmxp}_{i t}\end{array}\right\}, \quad \alpha_{i}(i=1 \ldots .53)$ is the unknown intercept for each country.

According to Alege and Ogundipe (2014), the fixed model is relevant as it enables us to sieve out the unobserved effect across entities, thereby making changes in dependent variable to be absolutely explained by influences from the observed pollution predictors.

The random effect model, unlike the fixed, assumes that variations across countries are random and uncorrelated with the independent variables. The random effect specification takes the mean error $\varepsilon_{i}$ and random term $\varepsilon_{i t}$ as randomized. Both error components are assumed to be random variable with normal distribution which is independent identically distributed (i.i.d). These error components are uncorrelated with independent variable (Yaffee, 2013; Al sayed \& Sek, 2013; Alege \& Ogundipe, 2014), such that:

$$
\varepsilon_{i t} \sim N\left(0, \sigma_{\varepsilon}^{2}\right) \quad \varepsilon_{i} \sim\left(0, \sigma_{\varepsilon}^{2}\right)
$$

In choosing the consistent and efficient model between the fixed effect and random effect model; we adopted the Hausman test. The test is considered as a Wald $X^{2}$ test with $(k-1)$ degrees of freedom where $k$ is the number of regressors in the model. The Hausman statistic is model as follows:

where $q=\beta_{F E}-\beta_{R E}$

$$
m=q^{\prime}\left[\operatorname{var}\left(\beta_{F E}\right)-\operatorname{var}\left(\beta_{R E}\right)\right]^{-1} q
$$

Under random effects model, the matrix difference in brackets is positive, as the random effects estimator is efficient and any other estimator has a larger variance. Under the null hypothesis, both FE and RE model are consistent with RE more consistent. Under the alternative hypothesis, FE is more efficient than RE. Therefore, the rejection of null hypothesis will suggest the choice of FE model (Yaffee, (2003), Al Sayed and Sek, (2013)).

\subsection{Data Sources and Measurement}

The data series required to empirically investigate the nature of EKC in Africa and the major income classification groups were sourced from the World development indicators of the World Bank 2013. These variables include; environment degradation proxied by Carbon dioxide $\left(\mathrm{CO}_{2}\right)$ emissions, gross domestic per capita income, population density, stock of external debt while manufactured export and regulatory quality were obtained from the data market of Iceland and World Governance Indicators. 
Table 4. Data sources and measurement

\begin{tabular}{llll}
\hline Variable & Symbol & Sources & measurement \\
\hline Environmental degradation & $E v d g$ & World Development Indicators (WDI) & $\mathrm{CO}_{2}$ emissions in Kilowatt tons \\
GDP Per Capita & $g p c i$ & World Development Indicators (WDI) & Constant US\$ \\
Population density & $P d e n$ & World Development Indicators (WDI) & People per Sq. km of land area \\
External debt & Extd & World Development Indicators (WDI) & Total external debt stock \\
& & & US\$ billion \\
Manufactured export & $M f x p$ & Data market of Iceland & Constant US\$ \\
Regulatory quality & $\operatorname{Regq}$ & World Governance Indicators (WGI) & Index \\
\hline
\end{tabular}

\section{Discussion of Result}

In an attempt to ascertain the pattern and nature of EKC in Africa, the study begins by estimating the basic EKC model for Africa and various income groups according to the World Bank classifications. The models were estimated using both fixed and random effects and the Hausman test was conducted to determine a reliable and consistent model. The fixed effect results were found consistent for Africa and Upper middle income model while the random effect result were consistent for Low income and Lower middle income models.

The result readily available in the table 5 below could not ascertain the existence of EKC in Africa, low income and upper middle income economies. Also, there exist an inverse relationship between economic degradation $\left(\mathrm{CO}_{2}\right.$ emissions) and income (GDP Per Capita) at the early stage of development. This reflects the extent of income inequality and the fact that the growth effort of most Africa economies is inclusive. Following the decision criteria of EKC parameter, especially from quadratic GDP per capita; the empirical investigation from Africa, Low income economies and Upper middle income economies shows evidence in support of a U-shaped relationship between pollution and income. Contrarily, the study confirms the EKC hypothesis in lower middle income countries though no reasonable turning point could be ascertained. The realization of EKC in lower middle income countries and the positive relationship between $\mathrm{CO}_{2}$ emissions and income at the early development stage is hinged on the reality that about 70 percent of economies in this category are oil exporting countries. Since gas flaring constitute a major source of $\mathrm{CO}_{2}$ among Africa oil producing economies and oil proceeds in most cases account for over 90 percent foreign earnings; there tends to exist a natural relationship between emissions and environmental degradation in Lower middle income countries.

Table 5. Basic EKC model for Africa

\begin{tabular}{lcccc}
\hline Variable & Africa $^{\mathbf{a}}$ & Low income $^{\mathbf{b}}$ & Lower middle $^{\mathbf{c}}$ & Upper middle $^{\mathbf{d}}$ \\
\hline Lpci & -0.4217 & $-2.1578^{*}$ & $4.5566^{*}$ & -6.2293 \\
lpci $^{2}$ & $0.1311^{*}$ & $0.2871^{*}$ & $-0.2189^{* *}$ & 0.4608 \\
C & $4.5422^{*}$ & $9.7915^{*}$ & $-13.2790^{*}$ & 28.5235 \\
F-test Prob.* & 0.0000 & & & 0.0000 \\
W-test Prob.* & & 0.0000 & 0.0000 & \\
Hausman & $14.47^{*}$ & 3.57 & 0.04 & $8.39^{*}$ \\
EKC & No & No & Yes & No \\
Obs & 758 & 435 & 192 & 116 \\
\hline
\end{tabular}

Authors' computation using Stata 11.0

Note: ${ }^{a}$ Africa is the EKC result for fifty three Africa countries ${ }^{b}$ Low income comprises thirty countries with GDP Per Capita of $\$ 1,035$ or less ${ }^{\mathrm{c}}$ Lower middle comprises fourteen countries with GDP Per Capita between $\$ 1,036$ to $\$ 4085^{\mathrm{d}}$ Upper middle comprises of eight countries with GDP Per Capita between $\$ 4,086$ to $\$ 12,615$

The study proceeds to estimate the expanded EKC model for Africa and the income groups. A similar estimation procedure was conducted, this include the pooled ordinary least square, the fixed effect and random effect model. 
The fixed effect results satisfied the requirement of efficiency and consistency as shown by the Hausman test for all groups except the upper middle income Africa where random effect appears to be more efficient. Though the result presented in table 6 is an augmentation of the basic EKC model, the nature and pattern of EKC remain as obtained in the basic model. The empirical results from our study was consistent with Omotor and Orubu and Orubu (2012) who failed to achieve EKC for lack of access to safe water using 24 Africa countries. Also our evidences match the studies of Galeotti et al., (2006) and Coondoo and Dinda (2008) who could not find evidence to affirm the validity of EKC hypothesis for non-OECD countries, but inconsistent with Orubu and Awopegba (2009) and Osabuohien et al., (2014) who established EKC for $\mathrm{CO}_{2}$ emissions in Africa. More so, as shown in the augmented EKC analysis, population density exerts a significant positive influence on environmental degradation. It implies that as population density inreases, more pressure is exerted on economic resources and environmental services most especially in the quest for livelihood. This is a major experience in most Africa's semi-urban and rural communities where major means of livelihood is agriculture. Activities ranging from local mining, deforestation, bush burning, etc. have contributed to eroding environmental quality.

Also, the indicator of external debt (asides from Africa as a whole) was found to be statistically significant for only low income group, since almost all the economies in this category are heavily indebted poor countries and commodity exports. In effect, an attempt to export more to generate earnings for financing debt service and repayment tends to create more pollution and environmental degradation. Finally, the measure of institution (regulatory quality) was found significant across groups except in lower middle income, where EKC was realized. There is the need to strengthen regulatory quality in other income groups to adherence to environmental regulations, adoption of abatement measures and cleaner technologies.

Table 6. Expanded EKC model for Africa

\begin{tabular}{|c|c|c|c|c|c|c|c|c|c|c|c|c|}
\hline \multirow[t]{2}{*}{ Variable } & \multicolumn{3}{|c|}{ Africa } & \multicolumn{3}{|c|}{ Low income Africa } & \multicolumn{3}{|c|}{ Lower middle income Africa } & \multicolumn{3}{|c|}{ Upper middle income Africa } \\
\hline & Pols & Fixed & Random & Pols & Fixed & Random & Pols & Fixed & Random & Pols & Fixed & Random \\
\hline lpci & -0.7208 & $1.5327^{* *}$ & $1.5628^{*}$ & 2.3417 & $2.6891^{*}$ & $2.5382^{* *}$ & $34.3933^{*}$ & 1.2465 & 4.6914 & $-9.5786^{* *}$ & -7.6913 & $-9.578^{* *}$ \\
\hline lpci2 & $0.0983^{* *}$ & -0.0395 & -0.0409 & -0.1272 & -0.1296 & -0.1145 & $-2.2426^{*}$ & $-0.0302^{*}$ & -0.2635 & $0.5611^{*}$ & $0.4725^{* * *}$ & $0.5611^{* *}$ \\
\hline lpden & $0.1355^{* *}$ & $0.4884^{* *}$ & $0.3460^{*}$ & $0.1344^{* *}$ & $0.4513^{*}$ & $0.1765^{* *}$ & $1.7141^{*}$ & $0.9192^{* *}$ & $0.7109^{* *}$ & $1.9654^{*}$ & $1.2424^{*}$ & $1.9654^{*}$ \\
\hline lextd & $0.9431^{* *}$ & $0.0502^{* *}$ & $0.0754^{* *}$ & $0.6377^{*}$ & $0.0804^{*}$ & $0.1166^{*}$ & $1.5003^{*}$ & 0.0473 & $0.1453^{* *}$ & -0.0371 & -0.0344 & -0.0371 \\
\hline $\operatorname{lmxp}$ & $0.1165^{* *}$ & 0.0131 & $0.0409^{*}$ & $0.1839^{*}$ & -0.0377 & 0.1141 & -0.0478 & 0.0708 & $0.1158^{*}$ & -0.0295 & -0.0376 & -0.0295 \\
\hline re & 0.0212 & $-0.1084^{* *}$ & $-0.1101^{* *}$ & $-0.2952^{*}$ & $-0.0894^{* *}$ & $-0.1023^{*}$ & $-1.8143^{*}$ & -0.1549 & -0.1643 & $-0.1680^{*}$ & $-1.5834^{* *}$ & $-0.1680^{*}$ \\
\hline $\mathrm{c}$ & -14.888 & -3.1766 & $-4.0435^{* *}$ & $-19.6984^{*}$ & $-6.4194^{* *}$ & $-6.6966^{* * *}$ & $-162.9025^{*}$ & -4.7539 & $-20.1052^{* * *}$ & $48.3631^{*}$ & $40.6901^{* *}$ & $48.3631^{*}$ \\
\hline F-(prob.*) & 0.0000 & 0.0000 & & 0.0000 & 0.0000 & & 0.0000 & 0.0000 & & 0.0000 & 0.0000 & \\
\hline $\mathrm{R}^{2}$ & 0.7395 & & & 0.7263 & & & 0.8240 & & & 0.9990 & & \\
\hline W-(prob.*) & & & 0.0000 & & & 0.0000 & & & 0.0000 & & & 0.0000 \\
\hline \multirow[t]{2}{*}{ Hausman } & & YES & & & YES & & & YES & & & & YES \\
\hline & & $14.47^{*}$ & & & $12.84^{*}$ & & & $19.28^{*}$ & & & & $2.53^{*}$ \\
\hline Pesaran & & 1.155 & & & 1.5372 & & & 1.8266 & & & & -1.321 \\
\hline test & & $(0.2479)$ & & & $(0.351)$ & & & $(0.352)$ & & & & $(0.427)$ \\
\hline Wald test & & 5702.80 & & & 200.45 & & & 11390.9 & & & & \\
\hline \multirow[t]{2}{*}{ LM test } & & & & & & & & & & & & 1.63 \\
\hline & & & & & & & & & & & & $(0.2011)$ \\
\hline
\end{tabular}

Source: Authors' computation using stata 11.0

Note: Pols indicates ordinary pooled regression estimates

In ensuring the reliability of our estimates for policy inferences, decision making and forecasting; the study conducted some sensitivity checks which include:

i. The Pesaran cross sectional dependence/contemporaneous correlation test. This is imputed as simply Pesaran test in table 6. The Pesaran test was conducted to test whether the residuals are correlated across entities. It 
becomes expedient to verify as cross sectional dependence can lead to a bias in test results. With the probability value of 0.2479 , the study accepted the null hypothesis that residuals are not correlated.

ii. The Modified Wald test for groupwise heteroskedasticity in fixed effect regression model, in this case the study failed to reject the null hypothesis of homoskedasticity or constant variance. This implies that our model is homoskedastic and therefore appropriate.

iii. Brensch-Pagan Lagrange multiplier (LM) test for random effects. The LM test helps to decide between a random effect regression and a simple OLS regression. The null hypothesis in the LM test suggests that variance across entities is zero, that is, there is no significant difference across units. In this case, the study failed to reject the null. Therefore, random effect is not appropriate does not significantly differ from pooled OLS.

Table 7. EKC model for Africa economies

\begin{tabular}{lcclcc}
\hline Country & EKC validity & Coefficient & Country & EKC validity & Coefficient \\
\hline Angola & No & -1.1650 & Libya & No & 4.0296 \\
Cameroon & No & 103.3699 & Madagascar & Yes & $-13.1664^{* *}$ \\
Algeria & No & 9.7965 & Malawi & No & 6.5551 \\
Benin & No & 88.5481 & Mali & No & 0.4271 \\
Botswana & Yes & $-2.6839^{* *}$ & Mauritania & No & -4.6553 \\
Burkina Faso & No & 1.5356 & Mauritius & Yes & $-2.2851^{*}$ \\
Burundi & No & -59.3307 & Morocco & Yes & $-1.5341^{* *}$ \\
Cape Verde & Yes & $-0.6192^{* *}$ & Mozambique & No & 0.3409 \\
CAR & No & 1.6830 & Namibia & No & 7.4616 \\
Chad & No & -3.7924 & Niger & No & 2.8685 \\
Comoros & No & -59.4313 & Nigeria & Yes & $-7.1375^{*}$ \\
Cote d'lvoire & No & -12.1309 & DR Congo & Yes & $-3.8369^{* *}$ \\
Congo & No & 0.9978 & Rwanda & No & 0.2553 \\
Djibouti & Yes & $-8.2856^{* *}$ & Sao tome & Yes & $-16.2608^{* *}$ \\
Egypt & Yes & $-1.4013^{* *}$ & Senegal & No & 4.1849 \\
Equatorial Guinea & No & -0.1593 & Seychelles & Yes & $-15.5827^{* *}$ \\
Eritrea & Yes & $-7.8439^{* *}$ & Sierra Leone & No & 2.9348 \\
Ethiopia & No & 0.8915 & South Africa & No & 1.6856 \\
Gabon & Yes & $-105.9452^{* *}$ & Sudan & Yes & $-3.5843^{* *}$ \\
Gambia & No & -12.5667 & Swaziland & No & -70.6240 \\
Ghana & Yes & $-3.1458^{* * *}$ & Tanzania & Yes & -0.1036 \\
Guinea & Yes & $-7.5665^{* *}$ & Togo & No & -17.7483 \\
Guinea-Bissau & No & 5.8552 & Tunisia & Yes & $-0.8123^{*}$ \\
Kenya & No & -2.2398 & Uganda & No & -0.7029 \\
Lesotho & Yes & $-149.6362^{* *}$ & Zambia & No & 1.4920 \\
Liberia & No & 0.04747 & Zimbabwe & No & 0.2330 \\
\hline Source:A & & & & \\
\hline
\end{tabular}

Source: Authors' computation using stata 11.0

The study also examine the pattern of EKC in individual countries of Africa, this is conducted to ensure the robustness of our parameter estimates and results. The results obtained confirm the foregoing analytical and empirical stands reached in previous sections. The estimation process involved the fifty three Africa countries, of which only nineteen affirmed the EKC hypothesis. Also, out of the nineteen that supported EKC hypothesis, ten were from the lower middle income group. Following the facts obtained from our analytical and empirical analyses, it therefore becomes imperative for policy makers to tread with caution on the implementation of 
findings and recommendation based on the erstwhile studies.

\section{Conclusion and Recommendation}

The study examines the pattern and nature of EKC in Africa and major income groups according to the World Bank income classification comprising low income, lower middle income and upper middle income in Africa. Also, for the purpose of ensuring robustness, the study ascertained the pattern of EKC in all Africa countries. We adopted a panel estimation procedure based on ordinary pooled regression, fixed and random effect regression and attained an efficient and consistent model with the aid of Hausman model selection criterion. More so, for the purpose of ensuring reliability of our parameter estimation for policy inferences, we carried out a series of sensitivity checks such as Pesaran residual correlation test, modified Wald test for heteroskedasticity and Brensch-Pagan LM test. Based on these tests, our models are void of biases and suitable for policy decision making.

An interesting observation however resulted in the study, though inconsistent with a number of extant studies, this would have resulted from our control of income heterogeneity and examining the nature of EKC among income groups. From our estimation results, we could not validate the EKC hypothesis in African countries (combined), low income group and upper middle income group but empirical and analytical evidences from lower middle income countries support the existence of EKC. This is not unconnected with the reality that majority of countries in lower middle income countries are oil-producing states, where oil proceeds contributes over 90 percent of foreign exchanges and constitute largest portion of budget financing; whereas, the extractive processes of crude oil constitute the largest contributors to $\mathrm{CO}_{2}$ in this economies.

Similarly, evidences from our robustness checks also confirmed the facts from the basic and augmented EKC model. As about 70 percent of countries with evidence in support of EKC hypothesis constitute the lower middle income group. Though, we could not attain a reasonable turning points as figures obtained were extremely low compared with extant studies, this might have resulted from the reality that majority of countries used in this study are grouped under the low income, and this group of low income countries constitute 60 percent of all countries in Africa. As in Lee et al. (2010), it may be suggested that GDP per capita of Africa countries have not yet received the perceived turning point. Similarly, Orubu and Awopegba (2009) assert that Africa is turning the corner of EKC much faster and at lower levels of income than expected.

Also, empirical evidences from African countries (combined) show that, low income and upper middle income where EKC could not be validated echoed strongly the need for strong institutional commitment to enforce policies that prohibit environmental pollution, check the activities of dirty multinationals, ensure equitable income distribution, encourage adoption of clean technologies and strategize environmental abatement measures.

\section{Acknowledgments}

The authors hereby recognize anonymous referees and participants at a $7^{\text {th }}$ Annual Conference of Nigeria Association of Energy Economist (NAEE) for their helpful comments

\section{References}

Agras, J., \& Chapman, D. (1999). A Dynamic Approach to the Environmental Kuznets Curve Hypothesis. Ecological Economics, 28, 267-277. http://dx.doi.org/10.1016/S0921-8009(98)00040-8

Al Sayed, A. R. M., \& Sek, S. K. (2013). Environmental Kuznets Curve: evidences from Developed and Developing Economies. Applied Mathematical Sciences, 7(33), 1081-1092.

Alege, P. O., \& Ogundipe, A. A. (2013). Environmental Quality and Economic Growth in Nigeria: A Fractional Cointegration Approach. International Journal of Development and Sustainability, 2(2).

Baliamoune-Lutz, M. (2011). Growth by Destination (where you export matters): Trade with China and Growth in African Countries. African Development Review, 23(2), 202-218. http://dx.doi.org/10.1111/j.1467-8268.2011.00281.x

Barrasi, M. R., Cole, M. A., \& Elliott, R. J. R. (2008). Stochastic Divergence or Convergence of Per Capita Carbon Dioxide Emissions: Re-examining the Evidence. Environmental and Resource Economics, 40(1), 121-137. http://dx.doi.org/10.1007/s10640-007-9144-1

Berkerman, N. (1992) Economic Growth and the Environment: Whose Growth? Whose Environment? World Development, 20(4), 481-496. http://dx.doi.org/10.1016/0305-750X(92)90038-W

Bulte, E., Lipper, L., Stringer, R., \& Zilberman, D. (2007). Payments for Ecosystem Services and Poverty reduction: Concepts, Issues, and Empirical Perspectives. Environment and Development Economics, 13(3), 
245-254.

Cole, M. A. (2000). Air pollution and 'Dirty' Industries: How and Why Does the Composition of Manufacturing Output Change with Economic Development? Environmental and Resource Economics, 17(1), 109-123. http://dx.doi.org/10.1023/A:1008388221831

Cole, M. A. (2004). Trade, the Pollution Haven Hypothesis and the Environmental Kuznets Curve: Examining the Linkages. Ecological Economics, 48, 71-81. http://dx.doi.org/10.1016/j.ecolecon.2003.09.007

Cole, M. A., Elliott, R. J. R., \& Fredriksson, P. G. (2006). Endogenous Pollution Havens: Does FDI influence environmental regulations? Scandinavian Journal of Economics, 108, 157-178. http://dx.doi.org/10.1111/j.1467-9442.2006.00439.x

Coondoo, D., \& Dinda, S. (2002). Causality between Income and Emission: A Country Group Specific $\begin{array}{llll}\text { Econometric } & \text { Analysis. } & \text { Ecological 351-367. }\end{array}$ http://dx.doi.org/10.1016/S0921-8009(01)00280-4

Coondoo, D., \& Dinda, S. (2008). Carbon Dioxide Emission and Income: A Temporal Analysis of Cross-country $\begin{array}{lllll}\text { Distributional } & \text { Patterns. } & \text { Ecological } & \text { Economics, } & 65,\end{array}$ http://dx.doi.org/10.1016/j.ecolecon.2007.07.001

Galeotti, M., Lanza, A., \& Pauli, F. (2006). Reassessing the Environmental Kuznets Curve for $\mathrm{CO}_{2}$ Emissions: A $\begin{array}{lllll}\text { Robustness } & \text { Exercise. } & \text { Ecological } & \text { Economics, } & \text { 57(1), }\end{array}$ http://dx.doi.org/10.1016/j.ecolecon.2005.03.031

Grossman, G., \& Krueger, A. (1991). Environmental Impacts of a North America Free Trade Agreement, Natural Bureau of Economy. Research Working Paper No. 3194, Cambridge: NBER.

Halicioglu, F. (2009). An Econometric Study of CO2 emissions, Energy Consumption, Income and Foreign Trade in Turkey. Energy Policy, 37(3), 1156-1164. http://dx.doi.org/10.1016/j.enpol.2008.11.012

Hollander, J. M. (2003). The Real Environmental Crisis: Why Poverty, Not Affluence, Is the Environment's Number One Enemy. Berkeley, Calif, University of California Press, 2003.

Holtz-Eakin, D., \& Selden, T. M. (1995). Stocking the fires? CO2 Emissions and Economic Growth. Journal of Public Economics, 57, 85-101. http://dx.doi.org/10.1016/0047-2727(94)01449-X

Khanna, N. (2002). The Income Elasticity of Non-point Source Air Pollutants: Revisiting the Environmental Kuznets Curve. Economics Letters, 77, 387-392. http://dx.doi.org/10.1016/S0165-1765(02)00153-2

Lee, C., Chiu, Y., \& Sun, C. (2010). The Environmrntal Kuznets Curve Hypothesis for Water Pollution: Do Regions Matter? Energy Policy, (38), 12-23. http://dx.doi.org/10.1016/j.enpol.2009.05.004

Lumsdaine, R., \& Papell, D. (1997). Multiple Trend Breaks and the Unit Root Hypothesis. Review of Economics and Statistics, 79, 212-218. http://dx.doi.org/10.1162/003465397556791

Narayan, P. K., \& Smyth, R. (2007). A Panel Cointegration analysis of the Demand for Oil in the Middle East. Energy Policy, 35(12), 6258-6265. http://dx.doi.org/10.1016/j.enpol.2007.07.011

Nguyen, V. P. (2005). Distribution Dynamics of CO2 Emissions. Environmental and Resource Economics, 32.

Omotor, D. G., \& Orubu, C. O. (2012). Searching for Environmental Kuznets Curve of Some Basics in Africa. Department of Economics, Delta State University, Abraka, Nigeria.

Orubu, C. O., Omotor, D. G., \& Awopegba, P. O. (2009). Economic Growth and Environmental Quality: Searching for Environmental Kuznets Curve in Africa. Paper presented at CSAE conference, University of Oxford, UK.

Osabuohien, E. S., Efobi, U. R., \& Gitau, C. M. (2004). Beyond the Environmental Kuznets Curve in Africa: Evidence from Panel Cointegration. Journal of Environmental Policy and Planning.

Panayotou, T. (1993). Empirical Tests and Policy Analysis of Environmental Degradation at Different Stages of Economic Development. Working Paper WP238, Technology and Employment Programme. ILO, Geneva.

Perman, R., \& Stern, D. I. (2003). Eevidence from Panel Unit Root and Cointegration Test that the Environmental Kuznets Curve Does Not Exist. Australian Journal of Agricultural and Resource Economics, 47(3), 325-347. http://dx.doi.org/10.1111/1467-8489.00216

Romero-Avila, D. (2008). Questioning the Empirical Basis of the Environmental Kuznets Curve for CO2: New Evidence from a Panel Stationary Test Robust to Multiple Breaks and Cross-Dependence. Ecological 
Economics, 64, 559-574. http://dx.doi.org/10.1016/j.ecolecon.2007.03.011

Schmidheiny, K., \& Basel, U. (2011). Panel Data: Fixed and Random effects.

Selden, T. M., \& Song, D. (1994). Environmental Quality and Development: Is there a Kuznet Curve for Air Pollution? Journal of Environmental Economics and Environmental management, 27(2), 147-162.

Shafik, N., \& Bandyopadhyay, S. (1992). Economic Growth and Environmental Quality: Time Series and Cross Country Evidence. Background Paper for World Development Report 1992, the World Bank, Washington, D.C.

Stanton, E. A. (2012). The tragedy of Mal-distribution: Climate, Sustainability and Equity. Sustainability, 4(3), 394-411. http://dx.doi.org/10.3390/su4030394

Stern, D. (2004). The Rise and Fall of the Environmental Kuznets Curve. World Development, 32(8), 1419-1439. http://dx.doi.org/10.1016/j.worlddev.2004.03.004

Stern, D. I., Common, M. S., \& Barbier, E. B. (1996). Economic Growth and Environmental Degradation: the Environmental Kuznets Curve and Sustainable Development. World Development, 24(7), 1151-1160. http://dx.doi.org/10.1016/0305-750X(96)00032-0

Strazicich, M., \& List, J. A. (2003). Are CO2 Emission Levels Converging among Industrialized Countries? Environmental and Resource Economics, 24, 263-271. http://dx.doi.org/10.1023/A:1022910701857

Suri, V., \& Chapman, D. (1998). Economic Growth, Trade and Energy: Implications for the Environmental Kuznets Curve. Ecological Economics. Special Issue on the Environmental Kuznets Curve. http://dx.doi.org/10.1016/S0921-8009(97)00180-8

Torres, M., \& Boyce, J. K. (1998). Income, Inequality and Pollution: A Reassessment of the Environmental Kuznets. Ecological Economics, 25(2), 195-208.

Villanueva, I. A. (2012). Introducing Institutional Variables in the Environmental Kuznets Curve: A Latin America study. In Annals of the constantin Brancusi University of Targu Jiu, Economy Series, Issue 1/2012. Retrieved February 2, 2014, from http://www.utgiiu.ro/revista/ec/pdf/201201/G_ITALO_ARBULU_VILLANUEVA.pdf

Westerlund, J., \& Basher, S. A. (2008). Testing the Convergence in Carbon Dioxide Emissions Using a Century of Panel Data. Environmental and Resource Economics, 40, 109-120. http://dx.doi.org/10.1007/s10640-007-9143-2

Wycoff, A. W., \& Rooop, J. M. (1994). The embodiment of Carbon in Imports of Manufactured Products: Implications for International Agreements on Greenhouse Gas Emissions. Energy Policy, 22(3), 187-194. http://dx.doi.org/10.1016/0301-4215(94)90158-9

Yaffee, S. (2002). Ecosystem Management in Policy and Practice. In G. Meffe, L. Nielsen, R. Knight, \& D. Schenborn (Eds.), Ecosystem Management: Adaptive, Community-Based Conservation. Washington, D.C.: Island Press.

\section{Notes}

Note 1. which asks whether pollution intensive industries are attracted to countries with low environmental regulations.

Note 2. The study adjusted the effect of geographical characteristics of different cities, time trend effects in levels of pollution, and location and type of pollution measurement device.

Note 3. According to Dinda, 2004; the trend of the relationship between the pollutants and the GDP can be determined by the following forms.

Note 4. Each entity has its own individual characteristics that may or may not influence the predictor variables.

\section{Copyrights}

Copyright for this article is retained by the author(s), with first publication rights granted to the journal.

This is an open-access article distributed under the terms and conditions of the Creative Commons Attribution license (http://creativecommons.org/licenses/by/3.0/). 